Foss. Rec., 24, 65-75, 2021

https://doi.org/10.5194/fr-24-65-2021

(C) Author(s) 2021. This work is distributed under

the Creative Commons Attribution 4.0 License.

\title{
Selenogonus narinoensis Stirton, 1947 (Tayassuidae, Cetartiodactyla, Mammalia): taxonomic status and paleobiogeographic implications
}

\author{
Germán M. Gasparini ${ }^{1}$, Oscar F. Moreno-Mancilla ${ }^{2,3}$, and José L. Cómbita ${ }^{2,4}$ \\ ${ }^{1}$ División Paleontología Vertebrados, Unidades de Investigación Anexo Museo de La Plata, Facultad de Ciencias Naturales y \\ Museo, Universidad Nacional de La Plata, Calle 122 y 60, CP 1900, Consejo Nacional de Investigaciones Científicas y \\ Técnicas (CONICET), La Plata, Buenos Aires, Argentina \\ ${ }^{2}$ Grupo de Investigación Biología Evolutiva y Epistemológica BIEVEP y Fundación BIEVEP, Calle 9, 4B-26, 15001 Tunja, \\ Boyacá, Colombia \\ ${ }^{3}$ Grupo de investigación en Sistemática Biológica SisBio, Universidad Pedagógica y Tecnológica de Colombia, Avenida \\ Central del Norte 39-115, 150003 Tunja, Boyacá, Colombia \\ ${ }^{4}$ Red de Ecoetología, Instituto de Ecología A. C., antigua Carretera a Coatepec 351, Colonia El Haya, Xalapa 91073, \\ Veracruz, Mexico
}

Correspondence: Germán M. Gasparini (germanmgasparini@gmail.com)

Received: 31 August 2020 - Revised: 27 November 2020 - Accepted: 8 December 2020 - Published: 29 March 2021

\begin{abstract}
The species Selenogonus narinoensis was described by Stirton (1947) based on a single specimen which comes from sediments cropping out in the Cocha Verde locality, Nariño Department (Colombia), tentatively referred to the late Pliocene-Pleistocene (MGN 931; IGM p002118, Museo Geológico Nacional, Servicio Geológico Colombiano, Bogotá). However, morphological studies and comparative morphometric observations of the specimen suggest that (1) no diagnostic character supports the validity of the species Selenogonus narinoensis (here considered species inquirenda); (2) a combination of features (e.g., the mandibular condyle located behind the posterior edge of the vertical mandibular ramus, the angular process which projects laterally outwards, a bunolophodont crown morphology, a mesodont crown height, and a simple crown morphology of the third lobe of $\mathrm{m} 3$ ) indicates it belongs to the genus Platygonus; (3) this specimen corresponds to one of the largest South American peccaries; (4) taking into account certain anatomical characters as well as its morphometric range, this specimen is assigned to Platygonus cf. marplatensis. Even though the stratigraphic provenance of the specimen is still doubtful, it can be proposed that (1) it could be one of the most ancient records of tayassuids in South America, as would be expected given its geographical position,
\end{abstract}

and (2) considering the new taxonomic proposal, this specimen represents the first record of Platygonus cf. marplatensis in Colombia and represents one of the northernmost South American records of the genus. This new interpretation would be of great relevance in the Great American Biotic Interchange due to its strategic geographical proximity to the Isthmus of Panama.

\section{Introduction}

The Tayassuidae (Mammalia, Cetartiodactyla) may have differentiated from their ancestor during the Eocene in Eurasia (Romer, 1966; Wright, 1998; Hulbert, 2001). Younger records suggest that the Tayassuidae expanded their range to North America from the late Eocene, where they reached their greatest diversity (Wright, 1998; Hulbert, 2001; Gasparini, 2007; Prothero, 2009; Prothero and Grenader, 2012; Prothero, 2015). From there they extended their distribution to South America during the Great American Biotic Interchange (GABI). They represent one of the first North American mammalian immigrants, after procyonids (Carnivora) and cricetid rodents (Woodburne, 2010; Cione et al., 2015; O’Dea et al., 2016). 
The oldest unequivocal records of fossil tayassuids in South America date back to the late Pliocene (ca. 43.3 Ma; see Prevosti et al., 2006; Gasparini, 2013) and were found in sediments cropping out in southeastern Buenos Aires Province, Argentina. In contrast, Frailey and Campbell (2012), followed by Prothero and Pollen (2013), support the hypothesis of an early arrival of the Tayassuidae in South America, earlier than late Miocene and well before most of the Great American Biotic Interchange (GABI) that had occurred by the late Pliocene (Cione et al., 2015; O'Dea et al., 2016). This is based on the supposed record of peccaries, among other mammals of Nearctic origin (e.g., gomphotheres, tapirs, dromomerycine ruminants), coming from the Madre de Dios Formation (late Miocene) outcrops in southeastern Peru (Frailey and Campbell, 2012; Prothero and Pollen, 2013; Prothero et al., 2014) and on the divergence times suggested by molecular analyses (Theimer and Keim, 1998; Gongora and Moran, 2005; Perry et al., 2017). However, the chronological information about the sediments containing these remains and their taxonomic assignment is not accurate (Perini et al., 2016; Parisi Dutra et al., 2017a; Gasparini et al., 2021). According to these authors, the supposedly extinct Miocene species are indistinguishable from modern tayassuids (Tayassu pecari and Dicotyles tajacu), and the stratigraphic provenance of the specimens is highly dubious, and the fossils are likely Quaternary in age.

Tayassuids have been found in late-Cenozoic deposits mainly in Argentina and Brazil but also in Uruguay, Bolivia, Colombia, Peru, and Venezuela (Rincón et al., 2009; Gasparini, 2013; Montellano-Ballesteros et al., 2014; Parisi Dutra et al., 2017b), with 6 genera and 12 species (Gasparini, 2013; Parisi Dutra et al., 2017c). Platygonus Le Conte, 1848a (late Pliocene-Early to Middle Pleistocene; Argentina, Uruguay, Bolivia, and Colombia), is represented by 5 species: Platygonus kraglievichi Rusconi, 1930 (late Pliocene-earliest Pleistocene; Argentina); Platygonus scagliai Reig, 1952 (late Pliocene-earliest Pleistocene; Argentina); Platygonus marplatensis Reig, 1952 (late Pliocene-earliest Pleistocene; Argentina); Platygonus chapadmalensis (Ameghino, 1908) (late Pliocene? latest Pliocene-earliest Pleistocene; Argentina); and Platygonus cinctus (Ameghino, 1886) (Early to Middle Pleistocene; Argentina). Catagonus Ameghino, 1904 (late Pliocene? Early Pleistocene-Late Pleistocene/Early Holocene; Argentina and Uruguay), is represented by two species: Catagonus metropolitanus Ameghino, 1904 (Early to Middle Pleistocene; Argentina), and Catagonus bonaerensis (Ameghino, 1904) (Middle Pleistocene? Late Pleistocene/Early Holocene; Argentina and Uruguay). Brasiliochoerus Rusconi, 1930 (Middle Pleistocene-Late Pleistocene/Early Holocene; Argentina, Brazil, Bolivia, and Uruguay) is monospecific, Brasiliochoerus stenocephalus (Lund in Reinhardt, 1880). Parachoerus Rusconi, 1930 (Middle Pleistocene? Late Pleistocene-recent; with paleontological records in Argentina and Uruguay), is represented by two species: Parachoerus carlesi (Rusconi, 1930) (Middle Pleistocene? Late Pleistocene; Argentina), and Parachoerus wagneri (Rusconi, 1930) (Late Pleistocene/Early Holocenerecent; fossil records in Argentina and Uruguay and currently endemic to the Dry Chaco in Argentina, Bolivia, and Paraguay). Tayassu Fischer, 1814 (Middle Pleistocenerecent; fossil records in Argentina, Brazil, Uruguay, and Venezuela and currently inhabits southeastern Mexico to northern Argentina), has one extant species, Tayassu pecari (Link, 1795). Finally, Dicotyles Cuvier, 1816 (Middle Pleistocene-recent; fossil records in Argentina, Brazil, Peru, and Venezuela and currently from southwestern USA to north-central Argentina), has one extant species Dicotyles tajacu (Linnaeus, 1758).

In Colombia, very few remains of tayassuids have been registered (Stirton, 1947; Villarroel et al., 1989; Gasparini, 2013; Moreno Mancilla et al., 2019). One of them is the holotype and single specimen of Selenogonus narinoensis Stirton, 1947, which comes from sediments cropping out at the Cocha Verde locality, Nariño Department, tentatively referred to the late Pliocene-Pleistocene. However, the chronological information of the fossil-bearing sediments is not accurate. In turn, Menégaz and Ortiz Jaureguizar (1995), considering the hypotheses of Kraglievich (1959, pp. 233234) and Reig (1981, p. 41), suggested a lower- to middlePliocene age for those fossil-bearing sediments. Fossil remains described as Platygonus sp. were found in sediments cropping out in the Villa de Leyva locality (Boyacá Department), but chronologic and stratigraphical information is still unknown (Gasparini et al., 2019). Other Tayassuidae remains were registered in Late Pleistocene sediments cropping out in the paleontological site named Los Hoyos located at the Tatacoa Desert (Huila Department) (Tayassu aff. tajacu sensu Villarroel et al., 1989).

The goals of this contribution are (1) to report the results of study of the fossil specimen from Nariño (Colombia); (2) to comment on the systematic validity of Selenogonus narinoensis Stirton, 1947; and (3) to discuss the paleobiogeographic and paleoecological significance of this peccary.

\section{Material and methods}

\subsection{Repositories and institutional abbreviations}

AMNH: American Museum of Natural History, New York, USA; ANSP: Academy of Natural Sciences of Drexel University, Philadelphia, USA; MACN: Museo Argentino de Ciencias Naturales "Bernardino Rivadavia", Ciudad Autónoma de Buenos Aires, Argentina; MLP: Museo de La Plata, Argentina; MGN: Museo Geológico Nacional, Bogotá, Colombia; MMP: Museo Municipal de Mar del Plata, Buenos Aires, Argentina; UF: Florida Museum of Natural History, University of Florida, Gainesville, FL, USA. 
The studied specimen (MGN 931; IGM p002118) is housed at the Museo Geológico Nacional (MGN), Servicio Geológico Colombiano (Bogotá, Colombia). Taxonomic classification follows the proposal of Parisi Dutra et al. (2017c). For nomenclatural assignments of collared and white-lipped peccaries, we followed Acosta et al. (2020).

The material was compared with North American and South American extinct and extant tayassuids. The following materials were included in the morphometric comparisons: Platygonus sp. - UF 10422, UF 8922, UF 12942, UF 62700, UF 66679, UF 63904, UF 67178, MACN 10959, MACN 5337, MMP 1139, MMP 1212; $P$. vetus - UF 220478, UF 221010, UF 221174, UF 220479, UF 221766, UF 221767; $P$. cf. $P$. vetus - UF 67177; P. cumberlandensis - UF w/"no." material, in exposition collection, AMNH 27871, AMNH 27872; P. compressus - AMNHFLA 6-90, AMNH Type 45724; P. kraglievichi - MACN Type 5341; P. scagliai - MMP-S 156, MMPS 553, MMP-M 878; P. marplatensis - MMP-S Type 25, MACN 19726; P. chapadmalensis - MMP-M 246. Measurements were taken using Vernier calipers, with $0.01 \mathrm{~mm}$ accuracy; data are expressed in millimeters.

\subsection{Measurements abbreviations}

Hrmv: height of the vertical branch of the mandible, taken from the ventral part of the angular process to the depression between the coronoid process and the condyle; Hrmhm3: depth of horizontal ramus below m3; Lm3: maximum length of molar 3 in a parallel line to the sagittal plane; Am3: maximum width of molar 3 in a perpendicular line to the sagittal plane.

\section{Systematic paleontology}

Class Mammalia Linnaeus, 1758

Order Cetartiodactyla Montgelard, Catzeflis, and Douzery, 1997

Suborder Suiformes Jaeckel, 1911

Infraorder Suoidea Gray, 1821

Family Tayassuidae Palmer, 1897

Subfamily Tayassuinae Palmer, 1897

Tribe Platygonini Parisi Dutra et al., 2017c

Genus Platygonus Le Conte, 1848a

1848a Platigonus, Le Conte, p. 103 (lapsus calami). 1848b Platygonus, Le Conte, p. 258. 1848a Hyops, Le Conte, p. 104. 1848b Protochoerus, Le Conte, pp. 105-106 (nomen dubium). 1852a Dicotyles, Le Conte (in part), p. 3.

1852b Dicotyles, Le Conte (in part), p. 5.

1853 Euchoerus, Leidy, p. 340.

1857 Dicotyles, Leidy (in part), p. 100.

1886 Antaodon, Ameghino, p. 149.

1887 Coyametla, Duges, p. 16.

1904 Listriodon, Ameghino, p. 76.

1930 Mylohyus, Rusconi, pp. 191-195

(nec Cope, 1889: p. 134).

1947 Selenogonus, Stirton, p. 322.

1959 Argyrohyus, Kraglievich, p. 230.

\section{Type species}

Platygonus compressus Le Conte, 1848a (ANSP 11512, ANSP 11515, ANSP 11522, ANSP 11524, ANSP 11533, ANSP 11534, ANSP 11539), Pleistocene sediments from a fissure fill near Galena, Jo Daviess County, Illinois, USA.

\section{Occurrence}

Late Miocene-Late Pleistocene (North America); late Pliocene-Early to Middle Pleistocene (South America). In South America there are paleontological records in Argentina (Buenos Aires and Jujuy provinces), Bolivia (Tarija valley), Uruguay (Canelones Department), and Colombia (Boyacá and Nariño departments) (Gasparini et al., 2010; Gasparini and Ubilla, 2011; Gasparini, 2013; Gasparini et al., 2019; Moreno Mancilla et al., 2019).

\section{Remarks}

The original spelling was actually "Platigonus", but there is sufficient indication that this was a misprint. The name is differently misprinted (Platydonus) in another paper by Le Conte, published almost simultaneously. "Platygonus is now universally used and may be retained" (Simpson, 1945, p. 146) (see McKenna and Bell, 1997). See also the International Code of Zoological Nomenclature (1999), articles 32 and 33.

\section{Platygonus marplatensis Reig, 1952}

1927 Homo chapadmalensis, Castellanos, pp. 1-15. 1941 Homo neogaeus (not Lehmann Nitsche, 1907), Vignati, pp. 274-358 (misidentification) 1952 Platygonus marplatensis, Reig, pp. 121-122. 1959 Argyrohyus chapadmalensis, Kraglievich, p. 230. 1977 Platygonus marplatensis, Wetzel, pp. 1-36. 1995 Platygonus marplatensis, Menégaz and Ortiz Jaureguizar, pp. 314-315.

2002 Platygonus marplatensis, Quintana, pp. 263-275. 2007 Platygonus marplatensis, Gasparini, pp. 178-183. 2013 Platygonus marplatensis, Gasparini, p. 58. 2017b Platygonus marplatensis, Parisi Dutra et al., p. 355. 


\section{Holotype}

MMP-S Type 25. Partial mandible. Layer 3, Chapadmalal Formation, Barranca de los Lobos, General Pueyrredón county, Buenos Aires Province, Argentina; late Pliocene (Fig. 1c).

\section{Occurrence}

Late Pliocene-earliest Pleistocene (Chapadmalalan Stage/Age, Marplatan Stage/Age (Sanandresian Substage/Subage sensu Cione et al., 2015); coastal cliff in Chapadmalal region and Miramar (General Pueyrredón and General Alvarado counties), in southeastern Buenos Aires Province, Argentina (Kraglievich, 1952; Reig, 1952; Quintana, 2002; Gasparini, 2004; Gasparini and Ubilla, 2011; Gasparini, 2013) (Fig. 2).

\section{Remarks}

Castellanos (1927) referred some teeth exhumed from the southeastern coast of Buenos Aires Province to Homo chapadmalensis. Vignati (1941) included these remains in the species Homo neogaeus Lehmann Nitsche, 1907, a species based on a fossil found in the Monte Hermoso cliff. Reig (1952) established the species Platygonus marplatensis based on a partial mandible found in the Chapadmalal Formation, Barranca de los Lobos, General Pueyrredón county, Buenos Aires Province. Kraglievich (1959) created the genus Argyrohyus with the species Argyrohyus chapadmalensis and included in the synonym Homo chapadmalensis Castellanos, 1927; Homo neogaeus sensu Vignati, 1941; and Platygonus marplatensis Reig, 1952. Menégaz and Ortiz Jaureguizar (1995) suggested that A. chapadmalensis could be a synonym of Platygonus marplatensis.

Concerning the specific reassignment, it is worth mentioning that Rusconi (1930) included the species Listriodon chapadmalensis Ameghino, 1908, in the genus Platygonus. This generates a case of secondary homonymy (they are homonyms as a consequence of a new combination and not as a consequence of origin), and it must be solved by priority. Thus, the species of Ameghino, 1908, may continue to be called Platygonus chapadmalensis, while for that of Castellanos, 1927, a replacement must be considered. Therefore, the oldest name is Platygonus marplatensis Reig, 1952 (see Wetzel, 1977; Gasparini, 2007, 2013; Parisi Dutra et al., 2017c).

Platygonus cf. marplatensis Reig, 1952

\section{Material examined}

Portion of vertical ramus of a left hemimandible with $\mathrm{m} 3$ partially preserved (Selenogonus narinoensis Stirton, 1947, holotype MGN 931 (IGM p002118)) (Fig. 1a, b).

\section{Occurrence}

Dark-green fine-grained sandstone exposed in Cocha Verde, Túquerres highway, Tangua Municipality, Nariño Department, Colombia. Late Pliocene or Pleistocene (sic Stirton, 1947, p. 322) (Fig. 2).

\section{Description}

This mandible corresponds to a large specimen. It has a shallow but sharply outlined masseteric fossa and a deep internal temporal fossa. The angular process projects forward to the middle part of $\mathrm{m} 3$, and its lower edge is slightly projecting laterally outwards. The lower border of the horizontal ramus is sharply hooked (accentuated) distally. The mandibular condyle is located behind the posterior edge of the vertical mandibular ramus. The coronoid process ascends behind $\mathrm{m} 3$.

The lower molar 3 only preserves the distal pair of main cusps (hypoconid and entoconid) and the third lobe, which has a well-developed single cusp, and a pair of smaller accessory cusps both located labially and lingually. Despite its incompleteness, a mesodont and bunolophodont dental morphology is observed.

\section{Measurements}

See Table 1.

\section{Discussion}

\subsection{Taxonomic comments and comparisons}

Stirton (1947) erected the genus and species Selenogonus narinoensis for this specimen based on some features that basically coincide with those of the Platygonus genus. Mainly these features are

Large, evidently about equal in size to Platygonus uquiensis Rusconi; masseteric fossa shallow but sharply outlined; internal temporal fossa deep; [...] ascending ramus relatively and actually higher than in other peccaries; angle below lower border of horizontal ramus, sharply hooked anteriorly; [...] m3 hypso-brachyodont; evidently more lophiodont than in Platygonus. (Stirton, 1947, p. 322)

However, these features do not differ from those described for Platygonus, given the diversity observed within the genus (Gasparini, 2007; Gasparini and Ubilla, 2011; De los Reyes et al., 2014). In addition, the following morphological features support the inclusion of this specimen within the genus Platygonus: mandibular condyle located behind the posterior edge of the vertical mandibular ramus, angular process projected laterally outwards, bunolophodont crown morphology, 


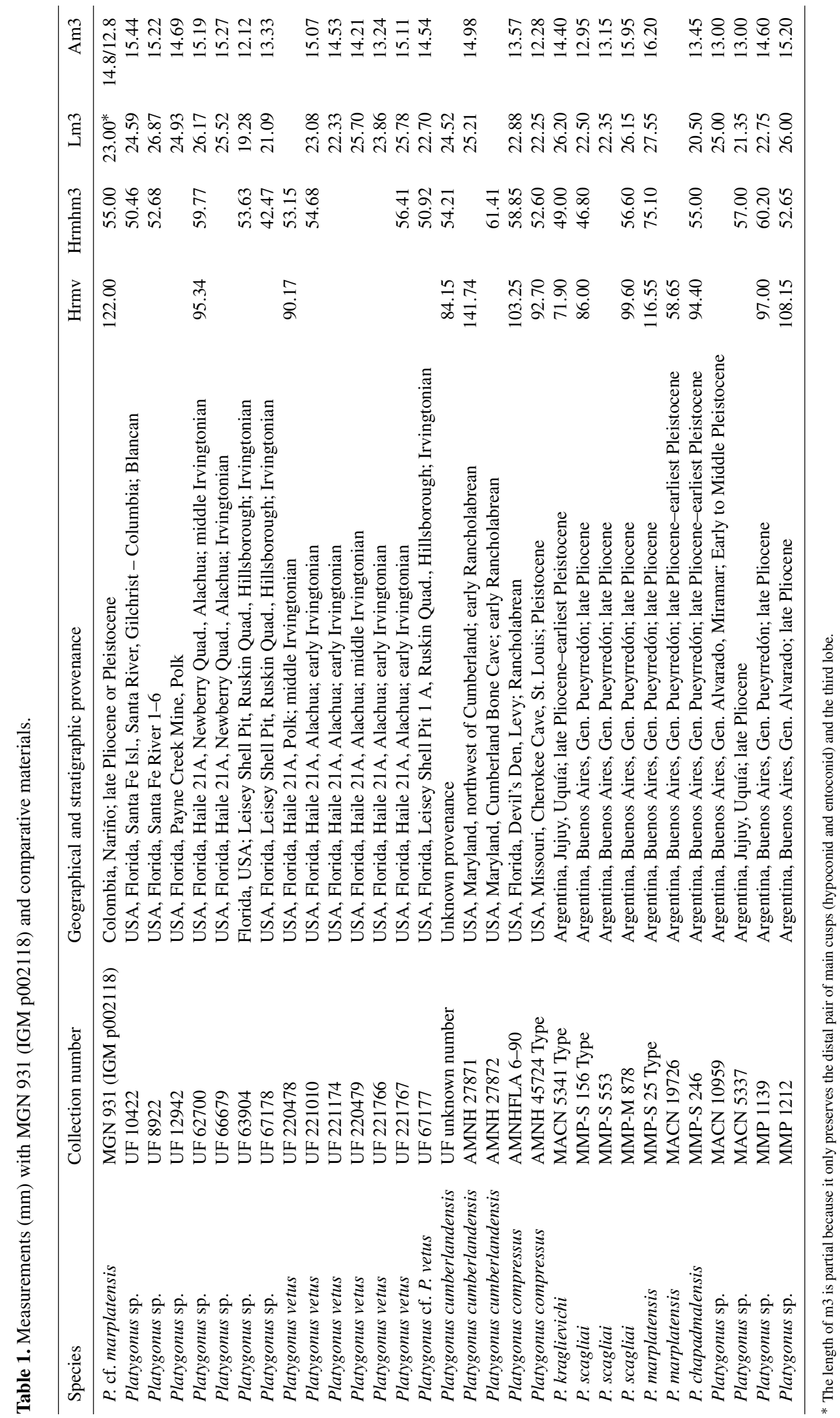




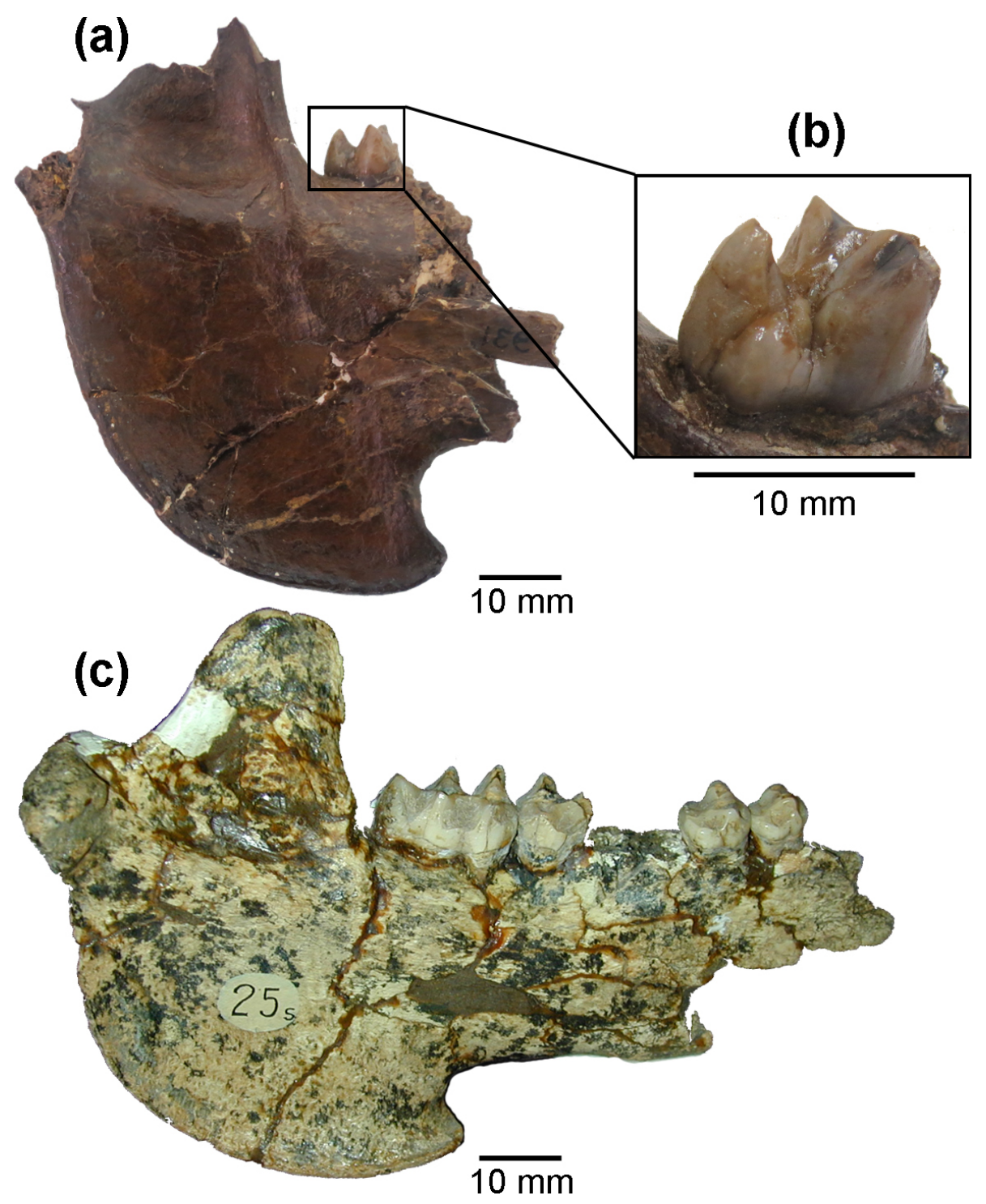

Figure 1. Platygonus cf. marplatensis MGN 931 (IGM p002118). (a) Lateral view of the portion of vertical ramus of the left hemimandible; (b) $\mathrm{m} 3$ partially preserved. Platygonus marplatensis MMP-S Type 25. (c) Lateral view.

mesodont crown height, and simple crown morphology of the third lobe of $\mathrm{m} 3$.

The development of mesodont and bunolophodont cheek teeth in Platygonus differs from the brachyodont and bunodont morphology observed in Tayassu pecari, Dicotyles tajacu, Parachoerus carlesi, and Brasiliochoerus stenocephalus; from the mesodont and bunodont cheek teeth typical of Catagonus metropolitanus and Catagonus bonaerensis; and from the mesodont crown height and bunodont with high crowns (referred to as "zygodont" by some authors (Gasparini, 2007; Prothero and Grenader, 2012; Gasparini et al., 2013)) observed in Parachoerus wagneri.

The sharp outline of the masseteric fossa is remarkable in the specimen studied. A similar condition was observed in Platygonus marplatensis, Platygonus chapadmalensis,
Platygonus sp. (MMP 1212), Brasiliochoerus stenocephalus among South American species, and Platygonus compressus among North American species.

The lower margin of the horizontal ramus in the specimen studied is also singular. A sharply hooked (accentuated) distal condition was observed only in the holotype of Platygonus marplatensis (MMP-S Type 25; see Fig. 1c). However, this character is not present in the other specimens assigned to this species (MACN 5420 type synonym, MMP-S 200, MMP-S 188, MMP-S 199, MMP-S 674, MACN 19725, MACN 19726) due to their partial preservation.

The incomplete state of preservation of the material prevents us from obtaining absolute measurements. However, taking into account its relative size, this specimen is within the proportions observed in species of the genus Platy- 


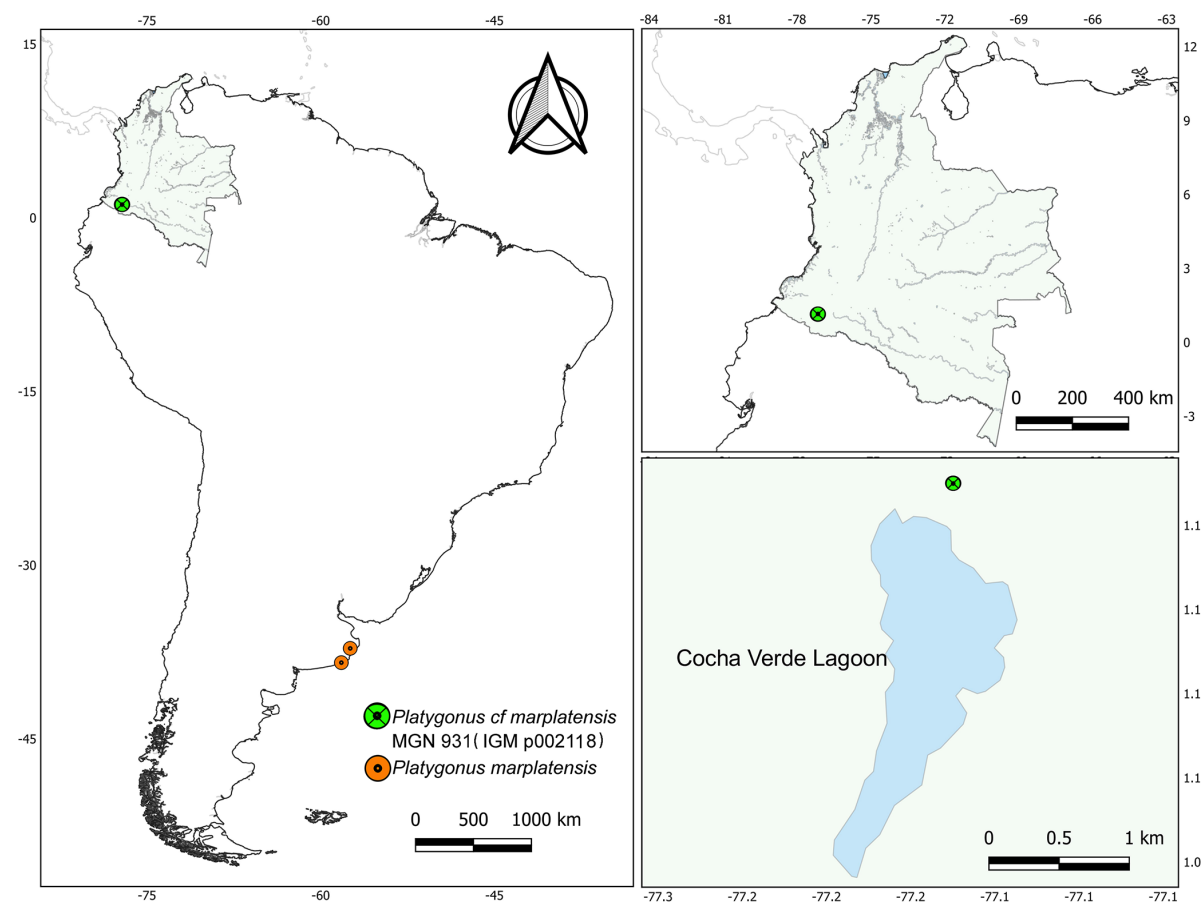

Figure 2. Geographical location of the MGN 931 (IGM p002118) and fossil records of Platygonus marplatensis in South America.

gonus (see Table 1). It is worth mentioning that the vertical mandibular ramus of this specimen is one of the largest among South American species, only comparable to P. marplatensis, $P$. chapadmalensis, and P. scagliai and to the largest specimens of North American Platygonus (e.g., Platygonus cumberlandensis Gidley, 1920).

The specimen under study has no diagnostic characters that support the species Selenogonus narinoensis as valid and identifiable (species inquirenda). The combination of features suggests it pertains to the genus Platygonus. As a consequence, based on the reflected taxonomic problems and taking into account certain anatomical characters (e.g., the position of the mandibular condyle, the outline and laterally outward projection of the angular process, the crown height and morphology of the tooth, and the distal condition of the lower margin of the horizontal ramus) as well as its morphometric range, this specimen is considered Platygonus $\mathrm{cf}$. marplatensis.

\subsection{Paleobiogeographical aspects}

The Tayassuidae represent one of the first North American immigrant mammals as well as the first ungulates that entered South America during the GABI (Gasparini, 2013; Cione et al., 2015; O'Dea et al., 2016).

According to phylogenetic analyses as well as chronological and geographical evidence, Platygonus represents a Tayassuidae lineage that originated in North America and corresponds to the first group of peccaries that entered South America during the late Pliocene (Prevosti et al., 2006; Gas- parini and Ubilla, 2011; Gasparini, 2013; De los Reyes et al., 2014; Parisi Dutra et al., 2017c). The greatest specific diversity of Platygonus is recorded during the late Pliocene-earliest Pleistocene in South America, mainly in Argentina (represented by $P$. marplatensis, $P$. chapadmalensis, P. scagliai, P. kraglievichi, and Platygonus sp.) and Uruguay (Platygonus sp.) (Gasparini and Ubilla, 2011; Gasparini, 2013, and bibliographies cited therein). If the stratigraphic provenance of the fossil specimen found in Nariño (Colombia) is confirmed, it could be one of the most ancient records of tayassuids on this continent, as would be expected given its geographical position. In addition, considering the new taxonomic proposal, this specimen represents the first record of Platygonus cf. marplatensis in Colombia. At the same time, it is remarkable that this Colombian record, together with the one registered in Villa de Leyva, represents the northernmost South American records of the genus Platygonus. This could have had great relevance in the Great American Biotic Interchange due to its strategic geographical proximity to the Isthmus of Panama.

In the Early to Middle Pleistocene, the taxonomic diversity and abundance of records of Platygonus are notably reduced (P. cinctus) and the genus Catagonus (C. metropolitanus) appears reliably for the first time in the paleontological record and only in Argentina (Gasparini, 2013).

The greatest specific diversity and abundance of tayassuids is documented during the Middle Pleistocene to Late Pleistocene-Early Holocene in South America (e.g., Argentina, Brazil, Uruguay, Bolivia, Peru, Colombia, and 
Venezuela) represented by Catagonus, Parachoerus, Brasiliochoerus, Tayassu, and Dicotyles (Gasparini, 2013; Parisi Dutra et al., 2017b). In the Middle Pleistocene the genera Brasiliochoerus, Tayassu, and Dicotyles and probably the species Parachoerus carlesi and C. bonaerensis appear for the first time in the South American fossil record (Gasparini, 2013). In the Late Pleistocene-Early Holocene, P. wagneri is registered for the first time (e.g., Uruguay) and $P$. carlesi and $C$. bonaerensis are reliably recorded (e.g., Argentina and Uruguay) on this continent. At the Pleistocene-Holocene boundary (about 10000 years ago) all megamammals and most of the large mammals became extinct in South America in a remarkable extinction event. The tayassuids were affected by this extinction, and only $25 \%$ of their taxonomic diversity has survived. Currently, peccaries are represented by only three species (Tayassu pecari, Dicotyles tajacu, and Parachoerus wagneri) (Gasparini, 2013; Parisi Dutra et al., 2017c; Acosta et al., 2020).

\subsection{Ecological and anatomical considerations}

The peccaries of the genus Platygonus have certain morphological features that allow some inferences about their habits: a great development of nasal sinuses and chambers, orbits located in a superior-posterior position and behind upper molar 3 due to elongation of the rostrum, a possession of a distinct basicranial flexure, a laterally outward projection of the angular process of the jaw (providing a greater surface for insertion of the lateral deep masseter muscle), a reduction of the lateral digits in the limbs, a mesodont crown height, and a bunolophodont crown morphology, among others. Therefore, this set of anatomical characters indicates that these large-sized peccaries have diurnal habits, a herbivorous diet, and probably a foraging habit and lived in dry and relatively open environments (Guilday et al., 1971; Wetzel, 1977; Menégaz and Ortiz Jaureguizar, 1995; Gasparini, 2007; Gasparini and Ubilla, 2011). Paleoecological studies (e.g., dental microwear and isotopic analysis) on North American Platygonus have shown a $\mathrm{C}_{3}$-browser to mixed-feeder diet and probably a $\mathrm{C}_{4}$-grass diet, under special conditions (Feranec and MacFadden, 2000; Feranec, 2007; Schmidt, 2008).

The faunal changes that have occurred since the late Pliocene could have been strongly influenced by climate (Cione et al., 2015, and references cited therein). The open and arid environments of great latitudinal extent developed during glacial cycles allowed the dispersion of Platygonus, Catagonus, Brasiliochoerus, and Parachoerus.

Based on paleontological records, as well as certain anatomical features (e.g., crown teeth morphology, limb development) linked to diet and life habits, together with body mass, it can be inferred that the species of Catagonus, Brasiliochoerus, and Parachoerus have replaced those of Platygonus since the Middle Pleistocene, probably as a consequence of the reduction of the open environments for which Platygonus species would be more specialized. This predom- inantly arid or semi-arid and cold period alternating with brief more humid and warmer pulses would have allowed the late expansion of the species of Tayassu and Dicotyles.

\section{Conclusions}

\subsection{Taxonomic final remarks}

Morphological studies and comparative morphometric observations of the Colombian specimen suggest that (1) no diagnostic character supports the validity of the species $\mathrm{Se}$ lenogonus narinoensis (here considered species inquirenda); (2) a combination of features (e.g., the mandibular condyle located behind the posterior edge of the vertical mandibular ramus, the angular process that projects laterally outwards, a bunolophodont crown morphology, a mesodont crown height, and a simple crown morphology of the third lobe of m3) indicates it belongs to the genus Platygonus; (3) this specimen corresponds to one of the largest South American peccaries; and (4) taking into account certain anatomical characters as well as its morphometric range, this specimen is assigned to Platygonus cf. marplatensis.

\subsection{Paleobiogeographical remarks}

Even though the stratigraphic provenance of the specimen found in Nariño (Colombia) is still doubtful (late Pliocene or Pleistocene?), it can be proposed that (1) it could be one of the most ancient records of tayassuids in South America, as would be expected given its geographical position, and (2) considering the new taxonomic proposal, this specimen represents the first record of Platygonus cf. marplatensis in Colombia and, together with the one registered in Villa de Leyva, establishes the northernmost South American records of the genus. This new interpretation would be of great relevance in the Great American Biotic Interchange due to its strategic geographical proximity to the Isthmus of Panama.

Sample availability. The studied specimen (MGN 931, IGM p002118) is housed at the Museo Geológico Nacional (MGN), Servicio Geológico Colombiano (Bogotá, Colombia). The holotype and referred materials for Platygonus marplatensis are housed at Museo Municipal de Mar del Plata and Museo Argentino de Ciencias Naturales "Bernardino Rivadavia" (Buenos Aires, Argentina).

Author contributions. GMG conducted the analysis and wrote the manuscript with contributions from all co-authors. OFMM prepared the figures. OFMM and JLC were in charge of the logistics to study the specimen (MGN 931, IGM p002118) housed at the Museo Geológico Nacional (MGN), Servicio Geológico Colombiano (Bogotá, Colombia). 
Competing interests. The authors declare that they have no conflict of interest.

Acknowledgements. The authors are grateful to Cecilia Deschamps, Darin Croft, Spencer G. Lucas and to the anonymous reviewer of a previous version and the final version of the manuscript for their valuable comments and suggestions and for improving the English version; to the Consejo Nacional de Investigaciones Científicas y Técnicas (CONICET) for permanent financial support; and to the authorities of paleontological collections (AMNH, MACN, MGN, MLP, MMP, UF) for providing material for analysis. This work was partially funded by 11/N864 UNLP, PICT-2017-0765, PICT-2016-2698, PIP 0496, and the Evolutionary and Epistemological Biology Investigation Group (BIEVEP).

Financial support. This work was partially funded by 11/N864 UNLP, PICT-2017-0765, PICT-2016-2698, PIP 0496, and the Evolutionary and Epistemological Biology Investigation Group (BIEVEP).

Review statement. This paper was edited by Torsten Scheyer and reviewed by Spencer G. Lucas and one anonymous referee.

\section{References}

Acosta, E. L., Garbino, G. T., Gasparini, G. M., and Parisi Dutra, R.: Unraveling the nomenclatural puzzle of the collared and white-lipped peccaries (Mammalia, Cetartiodactyla, Tayassuidae), Magnolia Press, 4851, 60-80, https://doi.org/10.11646/zootaxa.4851.1.2, 2020.

Ameghino, F.: Contribuciones al conocimiento de los mamíferos fósiles de los terrenos terciarios antiguos del Paraná, Bol. Acad. Nac. Cs. de Córdoba, 9, 5-228, 1886 (in Spanish).

Ameghino, F.: Nuevas especies de mamíferos cretáceos y terciarios de la República Argentina, Ann. Soc. Cient. Arg., 58, 1-188, 1904 (in Spanish).

Ameghino, F.: El arco escapular de los edentados y monotremos y el origen reptiloide de estos dos grupos de mamíferos, Ann. Mus. Nac. Buenos Aires, 10, 1-91, 1908 (in Spanish).

Castellanos, A.: Contribución al estudio de la Paleontropología argentina, Apuntes sobre el Homo chapadmalensis n. sp., Rev. Méd., 8, 1-15, 1927 (in Spanish).

Cione, A. L., Gasparini, G. M., Soibelzon, E., Soibelzon, L. H., and Tonni, E. P.: The Great American Biotic Interchange. A South American Perspective, in: Springer Brief Monographies in Earth System Sciences, South America and the Southern Hemisphere, edited by: Rabassa, J., Lohmann, G., Notholt, J., Mysak, L. A., and Unnithan, V., Springer, the Netherlands, https://doi.org/10.1007/978-94-017-9792-4, 1-97, 2015.

Cuvier, G.: Le règne animal distribué d'après son organisation, pour servir de base à l'histoire naturelle des animaux et d'introduction à l'anatomie comparée, Vol. 1. Les mammifères et les oiseaux. A. Belin, Paris, xxxvii, 1-540, 1816 (in French).

De los Reyes, M., Gasparini, G. M., Iacona, F., and Poiré, D.: Novedoso hallazgo de especímenes de Platygonus (Mammalia, Cetar- tiodactyla) en una paleocueva (Plioceno, Chapadmalalense) en la localidad de Olavarría, III Jornadas Paleontológicas del Centro, Olavarría, provincia de Buenos Aires, 12-13, 2014 (in Spanish).

Duges, A.: Platygonus alemanii. Nobis fosil cuaternario. La Naturaleza, per. cient., Soc. Mex. Hist. Nat., 1, 16-18, 1887 (in Spanish).

Feranec, R. S.: Ecological generalization during adaptive radiation: evidence from Neogene mammals, Evol. Ecol. Res., 9, 555-577, 2007.

Feranec, R. S. and MacFadden, B.: Evolution of the grazing niche in Pleistocene mammals from Florida: evidence from stable isotopes, Palaeogeo. Palaeoclim. Palaeoecol., 162, 155-169, 2000.

Fischer, G.: Zoognosia tabulis synopticis illustrata, Quadrupeda reliqua, Ceti Monotrymata, Nicolai Sergeidis Vsevolozsky, Moscow, 3, 1-732, 1814.

Frailey, C. D. and Campbell, K. E.: Two new genera of peccaries (Mammalia, Artiodactyla, Tayassuidae) from upper Miocene deposits of the Amazon Basin, J. Paleontol., 86, 852-877, 2012.

Gasparini, G. M.: Presencia de Tayassuidae en la Formación San Andrés (Plioceno tardío) en la región costera de Argentina central, Amegh. (Rev. Asoc. Paleontol. Arg.), 41R, 4, 47-48, 2004 (in Spanish).

Gasparini, G. M.: Sistemática, biogeografía, ecología y bioestratigrafía de los Tayassuidae (Mammalia, Artiodactyla) fósiles y actuales de América del Sur, con especial énfasis en las especies fósiles de la provincia de Buenos Aires, PhD dissertation, La Plata, Argentina, Universidad Nacional de La Plata, 1-504, 2007 (in Spanish).

Gasparini, G. M.: Records and stratigraphical ranges of South American Tayassuidae (Mammalia, Artiodactyla), J. Mamm. Evol., 20, 1, 57-68, 2013.

Gasparini, G. M. and Ubilla, M.: Platygonus sp. (Mammalia, Tayassuidae) in Uruguay (Raigón? Fm.; Pliocene-early Pleistocene), comments about its distribution and palaeonvironmental significance in South America, J. Nat. Hist., 45, 2855-2870, 2011.

Gasparini, G. M., Soibelzon, E., Zurita, A. E., and Miño-Boilini A. R.: A review of the Quaternary Tayassuidae (Mammalia, Artiodactyla) from the Tarija Valley, Bolivia, Alcheringa, 34, 7-20, 2010.

Gasparini, G. M., Ubilla, M., and Tonni, E. P.: The Chacoan peccary, Catagonus wagneri (Mammalia, Tayassuidae), in the late Pleistocene (northern Uruguay, South America): paleoecological and paleobiogeographic considerations, Hist. Biol., 25, 679-690, https://doi.org/10.1080/08912963.2012.742519, 2013.

Gasparini, G. M., Moreno Mancilla, F. O., and Cómbita, J. L.: "Selenogonus nariñoensis" Stirton (1947) (Tayassuidae, Artiodactyla, Mammalia): comentarios taxonómicos y biogeográficos, VII Simposio Colombiano de Biología Evolutiva "De regreso al origen, puntos de intersección entre el presente y el pasado". Tunja, Boyacá, Colombia, 2019 (in Spanish).

Gasparini, G. M., Parisi Dutra, R., Perini, F. A., Croft, D., Cozzuol, M. A., Missagia, R. V., and Lucas, S. G.: On the Supposed Presence of Miocene Tayassuidae and Dromomerycinae (Mammalia, Cetartiodactyla) in South America, American Museum Novitates, 3968, 1-27, 2021.

Gidley, J. W.: Pleistocene peccaries from the Cumberland Cave deposit, Proc. United States Nat. Mus., 57, 651-678, 1920. 
Gongora, J. and Moran, C.: Nuclear and mitochondrial evolutionary analyses of collared, white-lipped, and Chacoan peccaries (Tayassuidae), Mol. Phy. Evol., 34, 181-189, 2005.

Gray, J. E.: On the natural arrangement of vertebrose animals, London Med. Rep., 15, 296-310, 1821.

Guilday, J. E., Hamilton, H. W., and Mc Crady, A. D.: The Welsh Cave peccaries (Platygonus) and associated fauna, Kentucky Pleistocene, Ann. Carn. Mus. Nat. Hist., 43, 249-320, 1971.

Hulbert, C. H.: Mammalia, artiodactyls, in: The Fossil Vertebrates of Florida, edited by: Hulbert, R., University Press of Florida, Gainesville, 13, 242-279, 2001.

International Commission on Zoological Nomenclature: International Code of Zoological Nomeclature adopted by the XX General Assembly of the International Union of Biological Sciences, 4th Edn., XXX, 1-306, International Trust for Zoological Nomenclature, London, 1999.

Jaeckel, O. M. J.: Die Wirbeltiere, Eine Übersicht über die fossilen und lebenden Formen, Gebrüder Bornträger, Berlin, 1911.

Kraglievich, J. L.: El perfil geológico de Chapadmalal y Miramar, Provincia de Buenos Aires, Rev. Mus. Cs. Nat. Trad. Mar del Plata, 1, 8-37, 1952 (in Spanish).

Kraglievich, J. L.: Rectificación acerca de los supuestos molares humanos fósiles de Miramar (provincia de Buenos Aires), Rev. Inst. Antropol., 1, 223-236, 1959 (in Spanish).

Le Conte, J. L.: Notice of five new species of fossil Mammalia from Illinois, Am. J. Sc. and Arts, 2, 102-106, 1848a.

Le Conte, J. L.: On Platygonus compressus; a new fossil pachyderm, Mem. Am. Acad. of Arts and Scs., 3, 257-274, 1848b.

Le Conte, J. L.: Notice of a fossil Dicotyles from Missouri, Proc. Acad. Nat. Sc., 6, 3-5, 1852a.

Le Conte, J. L.: Notice of a fossil Dicotyles from Missouri, Proc. Acad. Nat. Sc., 6, 5-6, 1852b.

Leidy, J.: A memoir on the extinct peccary Dicotylinae of America, Trans. Am. Phil. Soc., 10, 323-343, 1853.

Leidy, J.: Observations on the extinct peccary of North America; being a sequel to "A memoir on the extinct Dicotylinae of America", Trans. Am. Phil. Soc., 11, 97-105, 1857.

Link, H. F.: Ueber die Lebenskraefte in naturhistorischer Rücksicht und die Classification der Saeugthiere, Beytraege zur Naturgeschichte, K. C. Stiller, Rostock und Leipzig, 2, 1-126, 1795 (in German).

Linnaeus, C.: Systema Naturae per regna tria naturae, secundum classes, ordines, genera, species, cum characteribus, differentiis, synonymis, locis. 10th edition, Laurentii Salvii, Stockholm, 1, 1-824, 1758 (in Latin).

McKenna, M. C. and Bell, S. K.: Classification of Mammals above the species level, Columbia University Press, New York, 1-640, 1997.

Menégaz, A. N., and Ortiz Jaureguizar, E.: Los artiodáctilos, in: Evolución biológica y climática de la región Pampeana durante los últimos cinco millones de años. Un ensayo de correlación con el Mediterráneo occidental, edited by: Alberdi, M. T., Leone, G., and Tonni, E. P., Museo de Ciencias Naturales, Consejo de Investigaciones Científicas, Monografías CSIC, Madrid, 311-335, 1995 (in Spanish).

Montellano-Ballesteros, M., Rincón, A. D., and Solórzano, A.: Record of tayassuids in late Pliocene to Quaternary deposits in Venezuela, Rev. Bras. Paleontol., 17, 169-182, 2014.
Montgelard, C., Catzeflis, F., and Douzery, E.: Phylogenetic relationships of artiodactyls and cetaceans as deduced from the comparison of cytochrome $b$ and 12S rRNA mitochondrial sequences, Mol. Biol. and Evol., 14, 550-559, 1997.

Moreno Mancilla, F. O., Cómbita, J. L., Gasparini, G. M., Soibelzon E., Soibelzon, L. H., Chimento, N. R., Parra, M. L., and Parra, J.: Mamíferos fósiles de Villa de Leyva (Boyacá, Colombia), VII Simposio Colombiano de Biología Evolutiva "De regreso al origen, puntos de intersección entre el presente y el pasado”. Tunja, Boyacá, Colombia, 2019 (in Spanish).

O’Dea, A., Lessios, H. A., Coates, A. G., Eytan, R. I., RestrepoMoreno. A., Cione, A. L., Collins, L. S., de Queiroz, A., Farris, D. W., Norris, R. D., Stallard, R. F., Woodburne, M. O., Aguilera, O., Aubry, M-P., Berggren, W. A., Budd, A. F., Cozzuol, M. A., Coppard, S. E., Duque-Caro, H., Finnegan, S., Gasparini, G. M., Grosmman, E. L., Johnson, K. G., Keigwin, Ll. D., Knowlton, N., Leigh, E. G., Leonard-Pingel, J. S., Marko, P. B., Pyenson, N. D., Rachello-Dolmen, P. G., Soibelzon, E., Soibelzon, L. H., Todd, J. A., Vermeij, G. J., and Jackson, J. B. C.: Formation of the Isthmus of Panama, Sc. Adv., 2, 8, https://doi.org/10.1126/sciadv.1600883, 2016

Palmer, T. S.: Notes on the nomenclature of four genera of tropical American mammals, Proc. Biol. Soc. Washington, 11, 173-174, 1897.

Parisi Dutra, R., Perini, F. A., Cozzuol, M. A., Missagia, R. V., and Gasparini, G. M.: On the supposed presence of Miocene Tayassuidae and Dromomerycinae (Mammalia, Artiodactyla) in South America, XXX Jornadas Argentinas de Mastozoología (SAREM). Bahía Blanca, Argentina, 181, 2017a (in Spanish).

Parisi Dutra, R., Velloso Missagia, R., Araujo Perini, F., Cozzuol, M. A., Gasparini, G. M., Goncalves Guedes, P., and Oliveira Salles, L.: Fossil peccaries of Late Pleistocene/Holocene (Cetartiodactyla, Tayassuidae) from underwater caves of Serra da Bodoquena (Mato Grosso do Sul State, Brazil), Hist. Biol., 29, 85-92, 2017b.

Parisi Dutra, R., de Melo Casali, D., Velloso Missagia, R., Gasparini, G. M., Araujo Perini, F., and Cozzuol, M. A.: Phylogenetic Systematics of Peccaries (Tayassuidae: Artiodactyla) and a Classification of South American Tayassuids, J. Mam. Evol., 24, 345-358, https://doi.org/10.1007/s10914-016-9347-8, 2017c.

Perini, F. A., Parisi Dutra, R., Cozzuol, M. A., Missagia, R. V., and Gasparini, G. M.: Fósseis de Artiodactyla da Amazönia Ocidental e implicacoes para o Grande Intercambio Biótico Americano, X Simpósio Brasileiro de Paleontologia de Vertebrados, IV Fórum do Grupo de Especialistas em Mamíferos Holárticos invasores. Museu Nacional/UFRJ, Rio de Janeiro, Brasil, 206, 2016 (in Spanish).

Perry, T., van Loenen, A. L., Heiniger, H., Lee, C., Gongora, J., Cooper, A., and Mitchell, K. J.: Ancient DNA analysis of the extinct North American flat-headed peccary (Platygonus compressus), Mol. Phy. Evol., 112, 258-267, https://doi.org/10.1016/j.ympev.2017.03.024, 2017.

Prevosti, F., Gasparini, G. M., and Bond, M.: On the systematic position of a specimen previously assigned to Carnivora from the Pliocene of Argentina and its implication for the Great American Biotic Interchange, N. Jahr. Geol. Paläontol. Abh., 242, 133-144, 2006.

Prothero, D. R.: The early evolution of the North American peccaries (Artiodactyla: Tayassuidae), in: Geology, Vertebrate Paleon- 
tology, and Biostratigraphy in Honor of Michael O. Woodburne, edited by: Albright, L. B., Mus. North. Ariz. Bull., 65, 509-541, 2009.

Prothero, D. R.: Evolution of the Early Miocene hesperhyine peccaries, New Mexico Mus. Nat. Hist. Sci. Bull., 67, 235-256, 2015.

Prothero, D. R. and Grenader, J.: A new primitive species of the flatheaded peccary Platygonus (Tayassuidae, Artiodactyla, Mammalia) from the Late Miocene of the High Plains, J. Paleontol., 86, 1021-1031, 2012.

Prothero, D. R. and Pollen, A.: New late Miocene peccaries from California and Nebraska, Kirtlandia, 58, 42-43, 2013.

Prothero, D. R., Campbell, K. E., Beatty, B. L., and Frailey, C. D.: New late Miocene dromomerycine artiodactyl from the Amazon Basin: implications for interchange dynamics, J. Paleontol., 88, 423-443, 2014.

Quintana, C. A.: Roedores cricétidos del Sanandresense (Plioceno tardío) de la provincia de Buenos Aires, Mastozool. Neotrop., 9, 263-275, 2002 (in Spanish).

Reig, O. A.: Descripción previa de nuevos ungulados y marsupiales fósiles del Plioceno y del Eocuartario argentinos, Rev. Mus. Mar del Plata, 1, 119-129, 1952 (in Spanish).

Reig, O. A.: Teoría del origen y desarrollo de la fauna de mamíferos de América del Sur, Monographiae Naturae, Mus. Mun. Cs. Nat. "Lorenzo Scaglia", 1, 1-162, 1981 (in Spanish).

Reinhardt, J.: De I de brasilianske knoglehuler fundne Navlesvin Arter, Videnskabelige Meddlelser fra den Naturhistorike Forening I Kjoberhavn, Copenhague, 271-301, 1879-1880 (in Danish).

Rincón, A. D., Parra, G., Prevosti, F., Alberdi, M. T., and Bell, C. H.: A preliminary assessment of the mammalian fauna from the Pliocene-Pleistocene El Breal de Orocual locality, Monagas State, Venezuela, in: Papers on geology, vertebrate paleontology and biostratigraphy in honor of MO Woodburne, edited by: Albright, L. B. and Flagstaff, A. Z., Mus. North. Ariz. Bull., 65, 593-620, 2009.
Romer, A. S.: Vertebrate paleontology, University of Chicago Press, Chicago, 468 pp., 1966.

Rusconi, C.: Las especies fósiles argentinas de pecaríes y sus relaciones con las del Brasil y Norteamérica, Ann. Mus. Nac. Hist. Nat. "Bernardino Rivadavia", 36, 121-241, 1930 (in Spanish).

Schmidt, C.: Dental microwear analysis of extinct Flat-heated Peccary (Platygonus compressus) from Southern Indiana, Proc. Ind. Acad. Sc., 117, 95-106, 2008.

Simpson, G. G.: The principles of classification and a classification of mammals, Bull. Am. Mus. Nat. Hist., 85, 1-350, 1945.

Stirton, R. A.: A rodent and a peccary from the Cenozoic of Colombia, Comp. Est. Geol. Oficiales en Colombia, 7, 317-324, 1947.

Theimer, T. C. and Keim, P.: Phylogenetic relationships of peccaries based on mitochondrial cytochrome b DNA sequences, J. Mam., 79, 566-572, 1998.

Vignati, M. A.: Los molares humanos fósiles de Miramar, Rev. Mus. La Plata, Antropol., 1, 274-358, 1941 (in Spanish).

Villarroel, C. A., Brieva, J. B., and Cadena, A.: Descubrimiento de mamíferos fósiles de edad Lujanense (Pleistoceno tardío) en el "desierto" de La Tatacoa (Huila, Colombia), Caldasia, 16, 119125, 1989 (in Spanish).

Wetzel, R. M.: The Chacoan peccary, Catagonus wagneri (Rusconi), Bull. Carn. Mus. Nat. Hist., 3, 1-36, 1977.

Woodburne, M. O.: The Great American biotic interchange: dispersals, tectonics, climate, sea level and holding pens, J. Mam. Evol., 17, 245-264, https://doi.org/10.1007/s10914-010-9144-8, 2010.

Wright, D. B.: Tayassuidae, in: Evolution of Tertiary Mammals of North America, Volume 1, Terrestrial Carnivores, Ungulates, and Ungulatelike Mammals, edited by: Janis, C. M., Scott, K. M., and Jacobs, L. L., Cambridge, Cambridge University Press, 389-400, 1998. 